Archive for

Organic Chemistry
Arkivoc 2019, ii, 0-0

to be inserted by editorial office

\title{
Ultrasound-assisted synthesis of imidazo[1,2-a]pyridines an d sequential one-pot preparation of 3-selanyl-imidazo[1,2-a]pyridine derivatives
}

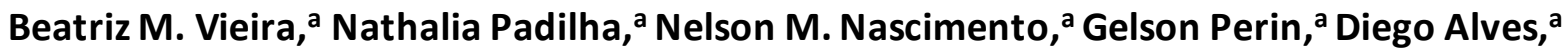 \\ Ricardo F. Schumacher, ${ }^{* a, b}$ and Eder J. Lenardão*a \\ a LASOL - CCQFA, Universidade Federal de Pelotas, UFPel-P.O. Box 354,96010-900, Pelotas, RS, Brazil \\ ${ }^{b}$ Departamento de Química, Universidade Federal de Santa Maria, UFSM, 97105-900, Santa Maria, RS, Brazil \\ E-mail: lenardao@ufpel.edu.br, ricardo.schumacher@ufsm.br
}

Dedicated to Professor Lorenzo Testaferri in the occasion of his $75^{\text {th }}$ birthday

Received 05-02-2019

Accepted 06-10-2019

Published on line 06-27-2019

\section{Abstract}

A simple and rapid method to synthesize imidazo[1,2-a]pyridines starting from 2-aminopyridine and 2bromoacetophenone derivatives under ultrasonic irradiation was developed. This protocol tolerates a wide range of 2-bromoacetophenone derivatives to produce a variety of imidazo[1,2-a]pyridines in good to excellent yields. Additionally, the one-pot preparation of 3-(organylselanyl)imidazo[1,2-a]pyridines via a sequential method is presented. In this case, different diorganyl diselenides were used as starting materials to afford the corresponding coupling products in excellent yields and short reaction times under sonication. The reactions were conducted in PEG-400, a cheap and nontoxic solvent, compatible with the ultrasound conditions in an environmentally benign process.

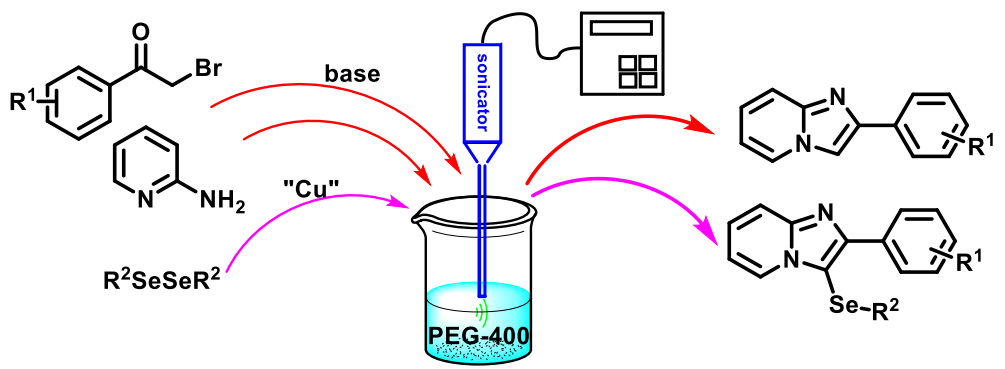

Keywords: Aminopyridine, diorganyl diselenides, imidazo[1,2-a]pyridines, PEG-400, ultrasound irradiation 


\section{Introduction}

$\mathrm{N}$-Heterocycles are structures found in natural and synthetic organic compounds relevant in many chemical and biological aspects. ${ }^{1}$ Among them, the imidazo[1,2-a]pyridines are one of the most studied class of heterocycles, due to their therapeutic use as antiviral, ${ }^{2}$ antituberculotic, ${ }^{3}$ antibacterial, ${ }^{4}$ antipsychotic ${ }^{5}$ and antitumor agents. ${ }^{6,7}$ In this way, the imidazo[1,2-a]pyridine scaffold is present in several established leading drugs, such as Alpidem, Necopidem, Olprinone, Saripidem, Zolimidine and Zolpidem.

In recent years, the synthesis and incorporation of different groups to the imidazo[1,2-a]pyridine unity, such as halogen, ${ }^{8,9}$ aryl, $^{10,11}$ formyl ${ }^{12,13}$ and chalcogen ${ }^{14-19}$ have attracted the attention of synthetic organic chemists, aiming to prospect for new drug candidates. Most of these methodologies, however, present drawbacks, such as tedious multistage synthesis and workup, the generation of large amounts of waste and a high effective cost. Some of these problems have been met, at least in part, by the use of multicomponent protocols, alternative energy sources and recyclable catalyst systems. ${ }^{20-24}$ For instance, Heibel and co-workers described a one-pot sequential microwave-assisted synthesis of 2-aryl-imidazo[1,2-a]pyridines in PEG-400, ${ }^{21}$ while Wei and co-workers used $\mathrm{CeCl}_{3} .7 \mathrm{H}_{2} \mathrm{O} / \mathrm{Nal}$ as a catalytic system to produce 3-sulfenylimidazo[1,2a]pyridines in ethanol under oxygen atmosphere. ${ }^{22}$ More recently, Allahabadi and co-workers developed a copper-catalyzed four-component synthesis of 2,3-disubstituted-imidazo[1,2-a]pyridines, ${ }^{23}$ while Zhang and Jiang described a solvent-free microwave-assisted multicomponent synthesis of 3-substituted-imidazo[1,2a]pyridines. ${ }^{24}$ Although the important improvement achieved by these methods, there is a research gap in the development of efficient and environmentally friendly protocols to access imidazo[1,2-a]pyridines directly attached to an organoselenium group.

Selenium-containing heterocycles are relevant in biochemical and pharmacological processes since several organoselenium compounds are known to exhibit interesting biological properties. ${ }^{25,26}$ Moreover, many organoselenium compounds have been used in a wide spectrum of organic reactions as precursors in the construction of functional materials. ${ }^{27,28}$ Thus, the synthesis and biological evaluation of selenium containing imidazo[1,2-a]pyridines are interesting fields of research, which combine at least two bioactive moieties in one molecule as an effective strategy for designing new pharmacologically promising drugs. ${ }^{4,29-32}$

In the last years, sonochemistry has established itself as an indispensable tool in drug discovery and green organic synthesis. ${ }^{33-37}$ Reactions promoted by ultrasound are faster due to the turbulent flow of the liquid phase caused by the cavitation, which enhances the mass transfer in heterogeneous systems. ${ }^{38,39}$ In this sense, due to our interest in the development of green procedures for the synthesis of biologically active organochalcogen-containing $N$-heterocycles, ${ }^{18,29,31,32,40,41}$ we describe here the ultrasound-promoted syntheses of imidazo[1,2-a]pyridines and 3-selanyl-imidazo[1,2-a]pyridines via a sequential one-pot reaction.

\section{Results and Discussion}

The initial experiments to optimize the reaction conditions were performed using 2-aminopyridine 1 and 2-bromoacetophenone $\mathbf{2 a}$ as model substrates to establish the best reaction conditions to prepare 2-phenylimidazo[1,2-a]pyridine 3a under ultrasound irradiation. In this study we have evaluated the influence of different bases and solvents, as well as the reaction time, as described in Table 1.

We started our studies by the reaction of 2-aminopyridine $1(0.5 \mathrm{mmol})$ with 2-bromoacetophenone $\mathbf{2 a}$ $(0.5 \mathrm{mmol})$ using $\mathrm{NaHCO}_{3}$ (1 equiv) as base in PEG-400 $(1.0 \mathrm{~mL})$ as the solvent. After sonication for $30 \mathrm{~min}$ 
(60\% of amplitude, $20 \mathrm{kHz}$ ), 2-phenyl-imidazo[1,2-a]pyridine 3a was obtained in 78\% isolated yield (Table 1, entry 1). With this result in hand, we turned our attention to testing different environmentally friendly solvents, such as glycerol, dimethylsulfoxide and ethanol (entries 2-4). PEG-400 proved to be the most suitable solvent for this reaction.

Aiming to check the necessity of base, a base-free reaction was performed, but in this case, only $39 \%$ yield of the expected product 3a was obtained after $30 \mathrm{~min}$ (Table 1, entry 5). From this point, a screening through different bases was conducted (Table 1, entries 6-12), which revealed that $\mathrm{K}_{2} \mathrm{CO}_{3}$ was superior under the ultrasound conditions (entry 7). An improvement in the reaction yield was achieved when the amount of $\mathrm{K}_{2} \mathrm{CO}_{3}$ was raised from 1.0 to 1.5 equiv, giving $3 a$ in $92 \%$ yield (Table 1 , entry 14 ). To our delight, when the reaction was sonicated for only $15 \mathrm{~min}$, a similar yield of 3 a was obtained (94\%), proving that the efficient energy-transfer by the ultrasonic irradiation can promote a fast reaction.

Table 1. Optimization of the reaction conditions to prepare imidazo[1,2-a]pyridine $3 \mathbf{a}^{a}$

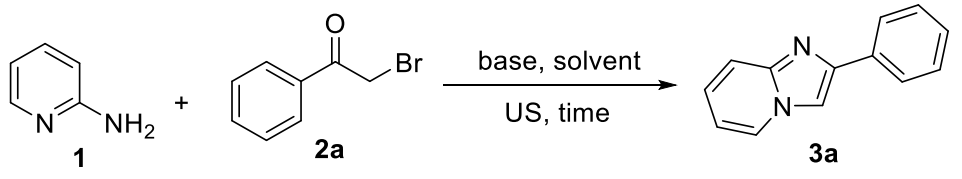

\begin{tabular}{|c|c|c|c|}
\hline Entry & Base (equiv) & Solvent & Yield (\%) \\
\hline 1 & $\mathrm{NaHCO}_{3}(1)$ & PEG-400 & 78 \\
\hline 2 & $\mathrm{NaHCO}_{3}(1)$ & Glycerol & 36 \\
\hline 3 & $\mathrm{NaHCO}_{3}(1)$ & DMSO & 67 \\
\hline 4 & $\mathrm{NaHCO}_{3}(1)$ & Ethanol & 11 \\
\hline 5 & - & PEG-400 & 39 \\
\hline 6 & $\mathrm{KOH}(1)$ & PEG-400 & 28 \\
\hline 7 & $\mathrm{~K}_{2} \mathrm{CO}_{3}(1)$ & PEG-400 & 81 \\
\hline 8 & $\mathrm{Cs}_{2} \mathrm{CO}_{3}(1)$ & PEG-400 & 33 \\
\hline 9 & $\mathrm{Et}_{3} \mathrm{~N}(1)$ & PEG-400 & 22 \\
\hline 10 & $\mathrm{~K}_{3} \mathrm{PO}_{4}(1)$ & PEG-400 & 63 \\
\hline 11 & ${ }^{t} \mathrm{BuOK}(1)$ & PEG-400 & 27 \\
\hline 12 & $\mathrm{KF} / \mathrm{Al}_{2} \mathrm{O}_{3}(1)$ & PEG-400 & NR \\
\hline 13 & $\mathrm{~K}_{2} \mathrm{CO}_{3}(1.2)$ & PEG-400 & 87 \\
\hline 14 & $\mathrm{~K}_{2} \mathrm{CO}_{3}(1.5)$ & PEG-400 & 92 \\
\hline $15^{b}$ & $\mathrm{~K}_{2} \mathrm{CO}_{3}(1.5)$ & PEG-400 & 94 \\
\hline
\end{tabular}

${ }^{\text {a }}$ Reactions performed using 2-aminopyridine $\mathbf{1}(0.5 \mathrm{mmol})$, 2-bromoacetophenone $\mathbf{2 a}$ $(0.5 \mathrm{mmol}$ ) and base in $1 \mathrm{~mL}$ of solvent, underultrasonic irradiation (60\% amplitude, $20 \mathrm{kHz}$ ) for $30 \mathrm{~min}$. ${ }^{b}$ Reaction performed for $15 \mathrm{~min}$. NR = No Reaction

Next, with the best reaction conditions found, the substrate scope was evaluated with respect to differently substituted 2-bromoacetotophenones $\mathbf{2 a}-\mathbf{h}$. These reactions led to the corresponding imidazo[1,2a]pyridines 3a-h (Table 2).

An inspection in the results of Table 2 shows that the expected imidazo[1,2-a]pyridines 3a-h were obtained in good to excellent yields at reaction times no longer than $30 \mathrm{~min}$. It can also be observed that the presence of electron-withdrawing or electron-releasing groups directly attached to the aryl moiety of the 
acetophenone does not affect significantly the reactivity of the carbonyl group. However, electron-poor starting acetophenones seems to be less reactive compared to the electron-rich ones (Table 2, entries 2-8).

Table 2. Imidazo[1,2-a]pyridines 3 synthesized under US ${ }^{a}$

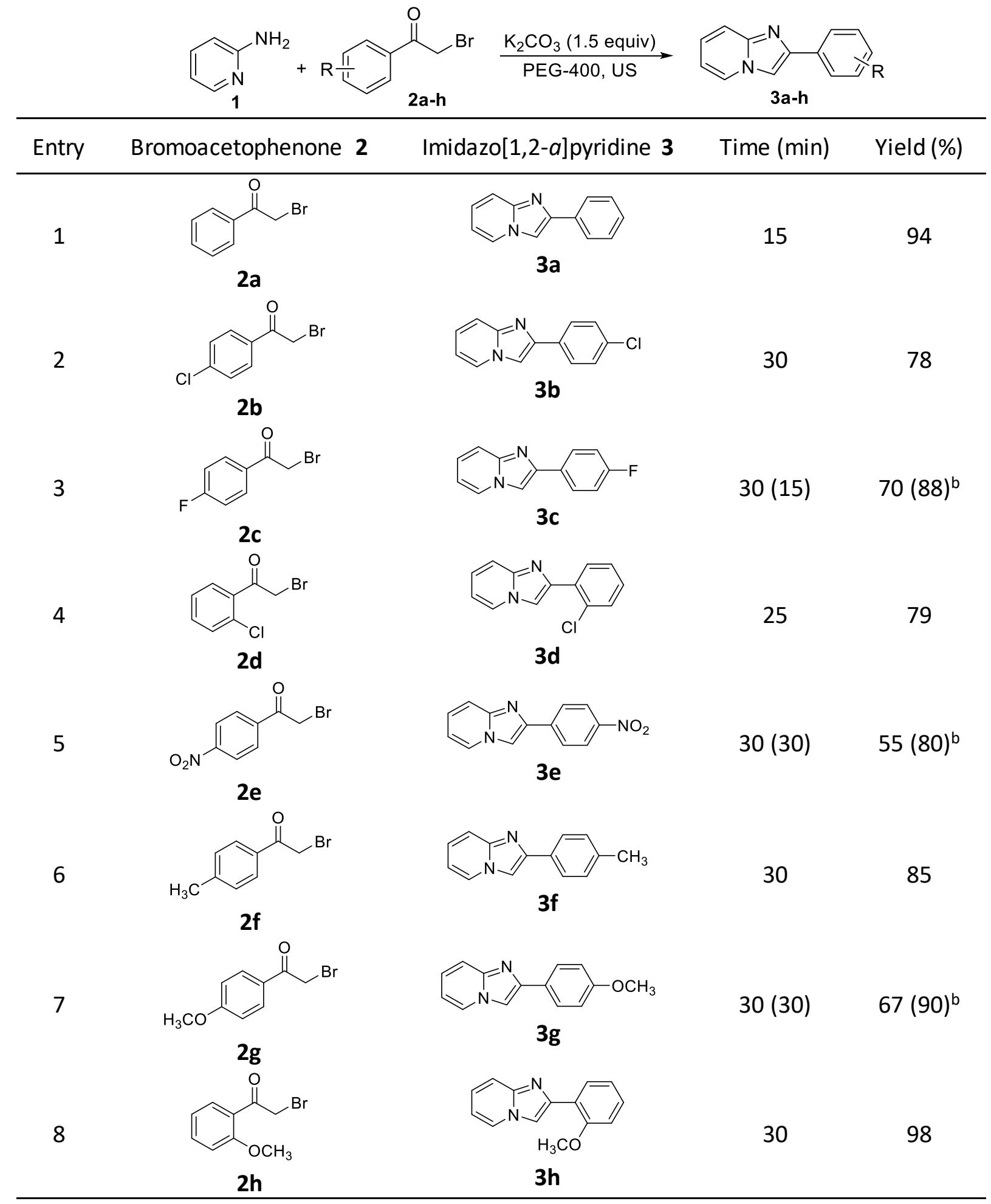

a Reactions were performed using 1 ( $0.5 \mathrm{mmol}), 2$ ( $0.5 \mathrm{mmol}), \mathrm{K}_{2} \mathrm{CO}_{3}$ (1.5 equiv, $\left.0.75 \mathrm{mmol}\right)$ in PEG-400 (1 mL) under ultrasonic irradiation (60\% of amplitude). $\quad{ }^{\mathrm{b}}$ Number in parenthesis refers to the reaction using 2 equiv of 1 (1.0 mmol). 
For example, the presence of fluorine or nitro groups in the phenyl ring of the 2-bromoacetophenones $2 c(R=$ $4-\mathrm{F})$ and $2 \mathrm{e}\left(\mathrm{R}=4-\mathrm{NO}_{2}\right)$, negatively influenced the reaction, and the respective products $3 c$ and $3 e$ were obtained in $70 \%$ and $55 \%$ yields (Table 2, entries 3 and 5). A similar decrease in reactivity was observed starting from the electron-rich 2-bromo-4'-methoxyacetophenone $(2 \mathrm{~g}, \mathrm{R}=4-\mathrm{OMe})$, and the expected product $3 \mathrm{~g}$ was isolated in $67 \%$ yield using the optimal conditions. Fortunately, better yields were obtained from these recalcitrant ketones when an excess of 2-aminopyridine $\mathbf{1}$ (2 equiv) was used, raising the yields of 3c, 3e and $\mathbf{3 g}$ to $88 \%$, $80 \%$ and $90 \%$, respectively, while reducing the reaction time to $15 \mathrm{~min}$ in the case of $3 \mathrm{c}$ (Table 2, values in parenthesis). Notably, these reactions do not suffer from steric effects of the substituents at 2 bromoacetophenone counterpart 2. For instance, the reactions using the sterically constrained 2-bromo-1-(2chlorophenyl)ethan-1-one $\mathbf{2 d}$ and 2-bromo-1-(2-methoxyphenyl)ethan-1-one $\mathbf{2} \mathbf{h}$, afforded the corresponding products $\mathbf{3 d}$ and $\mathbf{3 h}$ in $79 \%$ and $98 \%$ yields, which are close to those obtained starting from the unsubstituted 2-bromoacetophenone $\mathbf{2 a}$ (Table 2, entries 4 and 8 ). The possibility of obtaining chloro-substituted imidazo[1,2-a]pyridines $\mathbf{3 b}$ and $\mathbf{3 d}$ is noteworthy, once it allows the possibility of future reactions like TM-catalyzed couplings.

As mentioned before, the combination of $\mathrm{N}$-heterocycles with organochalcogen moieties is an interesting strategy to prospect for new compounds with increased pharmacological activities. ${ }^{29-32}$ In this line, the development of alternative, green methods based in ultrasound synthesis of organochalcogen-containing $\mathrm{N}$ heterocycles under non-conventional reaction media is an interesting field of research, in consideration of economic, environmental and health issues. ${ }^{42}$ Still, the growing interest in these compounds as promising new drugs, functional materials, catalysts and synthetic intermediates collaborate to reinforce the importance of this class of compounds. ${ }^{25,26}$ Thus, to extend the application of our US-assisted protocol, we decided to study the possibility of performing an one-pot sequential direct selanylation reaction of the pre-formed imidazo[1,2a]pyridines 3, aiming to prepare selanylimidazopyridines 5 (Table 3). We started our investigations using the reaction to form imidazo[1,2-a]pyridine 3a (Table 2, entry 1), with diphenyl diselenide $4 a$ as the selenylating species. After the preformation of $\mathbf{3 a}$ (15 $\mathrm{min}$ under sonication), diphenyl diselenide $4 \mathbf{4 a}$ (0.6 equiv) and the catalyst were added in the same vessel, without isolation of $\mathbf{3 a}$, and the sonication was continued for additional $2 \mathrm{~h}$ (Table 3 ). 
Table 3. Optimization of the reaction conditions for the direct selenylation of $3 \mathbf{a}^{a}$

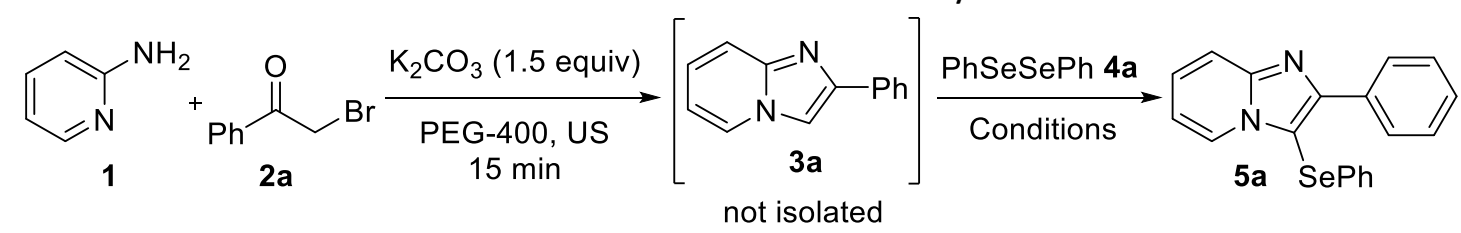

\begin{tabular}{|c|c|c|c|c|c|c|c|}
\hline Entry & Additive & $\begin{array}{r}\text { Amount } \\
\text { (equiv) }\end{array}$ & Yield (\%) ${ }^{b}$ & Entry & Additive & $\begin{array}{c}\text { Amount } \\
\text { (equiv) }\end{array}$ & Yield (\%) \\
\hline 1 & none ${ }^{c}$ & - & $N R^{d}$ & 6 & Cul & 2 & 42 \\
\hline 2 & NBS & 1.2 & 46 & 7 & $\mathrm{KI} \mathrm{CuSO}_{4}$ & $2 / 2$ & 95 \\
\hline 3 & $\mathrm{FeCl}_{3}$ & 1 & 31 & 8 & $\mathrm{KI} \mathrm{CuSO}_{4}$ & $1 / 1$ & 41 \\
\hline 4 & $\mathrm{I}_{2}$ & 2 & 80 & 9 & $\mathrm{KI}$ & 2 & $N R^{d}$ \\
\hline 5 & $\mathrm{CuBr}$ & 2 & 57 & 10 & $\mathrm{CuSO}_{4}$ & 2 & 38 \\
\hline
\end{tabular}

${ }^{a}$ Reactions were performed using initially $1(0.5 \mathrm{mmol}), 2 \mathrm{2a}(0.5 \mathrm{mmol}), \mathrm{K}_{2} \mathrm{CO}_{3}(0.75 \mathrm{mmol}, 1.5$ equiv.) in PEG400 (1.0 mL) under ultrasonic irradiation (60\% of amplitude) for $15 \mathrm{~min}$. After that, in the same vessel, $4 a(0.3$ $\mathrm{mmol}$ ) and the additive were added. The ultrasonic irradiation was continued for additional $2 \mathrm{~h}$. ${ }^{b}$ Yield is given for isolated product after the sequential two step one-pot procedure. ${ }^{c}$ An additional 1 equiv (0.5 mmol) of $\mathrm{K}_{2} \mathrm{CO}_{3}$ was added with the diselenide $4 a . \quad d$ At the end of the reaction, $3 a$ and $4 a$ were recovered. $\quad N R=$ no reaction.

Initially, the reaction was tested just by adding PhSeSePh $4 a$ and an additional amount of base $\left(\mathrm{K}_{2} \mathrm{CO}_{3} ; 0.5\right.$ $\mathrm{mmol}$ ) in the reaction vessel containing the preformed imidazo[1,2-a]pyridine 3a. Unfortunately, none of the expected product $\mathbf{5 a}$ was obtained after $2 \mathrm{~h}$ of sonication and the imidazo[1,2-a]pyridine $3 \mathrm{a}$ and diselenide $4 \mathrm{a}$ were recovered (Table 3, entry 1 ). Then, we decided to investigate the influence of different well-known reagents able to produce in situ electrophilic selenium species such as $\mathrm{NBS}, \mathrm{FeCl}_{3}, \mathrm{I}_{2}$, $\mathrm{KI}$ and copper salts (Table 3 , entries 2-7). Analysis of the preliminary reactions showed that moderate to excellent yields of the expected product 5a were obtained under US in PEG-400. Remarkably, when the reaction was carried out using a mixture of $\mathrm{KI} / \mathrm{CuSO}_{4}$ (2/2 equiv), the expected 5 a was obtained in $95 \%$ yield after $2 \mathrm{~h}$ (Table 3, entry 7 ). In order to evaluate the optimal amount of $\mathrm{KI}_{\mathrm{CuSO}}$, a reaction was conducted using 1 equiv of this mixture of salts. However, the yield of $\mathbf{5 a}$ was dramatically reduced to $41 \%$ (Table 3 , entry 8 ). When the reaction was performed using only $\mathrm{KI}$, consumption of the starting materials was not observed (Table 3, entry 9), while using $\mathrm{CuSO}_{4}$ alone produced only $38 \%$ yield of product 5 a (Table 3, entry 10 ). Thus, the best conditions in the one-pot reaction to prepare 3-phenylselanyl-imidazo[1,2-a]pyridine 5a requires sonication of a mixture of the preformed imidazo[1,2-a]pyridine 3a in PEG-400 with diphenyl diselenide 4a (0.6 equiv) in the presence of $\mathrm{KI} / \mathrm{CuSO}_{4}$ (2 equiv) for $2 \mathrm{~h}$ (Table 3 , entry 7 ).

The versatility and usefulness of our ultrasound-activated one-pot protocol was then extended to different diorganyl dichalcogenides 4 and imidazo[1,2-a]pyridine derivatives 3 (Table 4). As a general trend, it was observed that most of the reactions proceeded smoothly with good results. The direct chalcogenation showed to be general with respect to a wide array of diorganyl diselenides $4 \mathbf{a}-\mathbf{h}$, regardless their substitution patterns (Table 4, entries 1-8). 
Table 4. Synthesis of 3-selenyl-imidazo[1,2-a]pyridines 5a-q. ${ }^{a}$

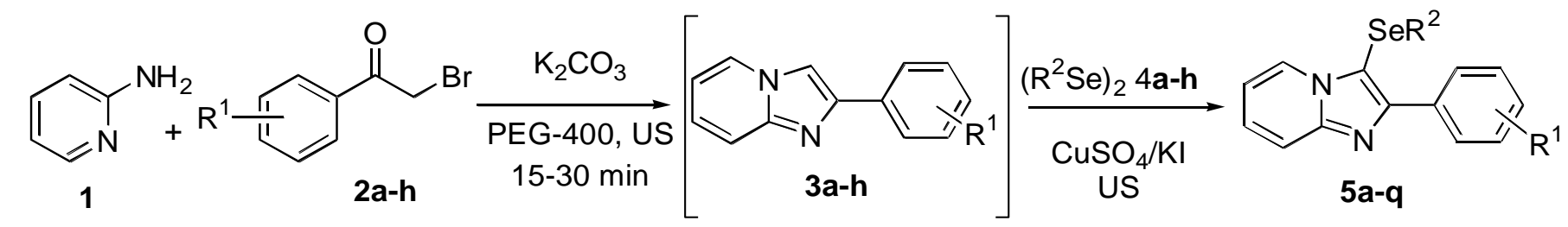

Entry 2-Bromoketone

2

$2 a$

3

$2 a$

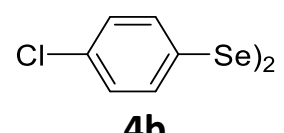

4b

$4 a$

Product 5

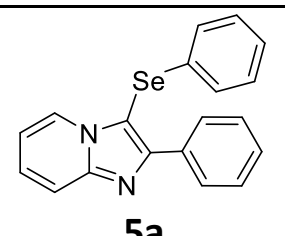

2

(h) Yield $(\%)^{a}$ 
8

$$
2 a
$$

9<smiles>O=C(CBr)c1ccc(Cl)cc1</smiles>

2b

10<smiles>[Z]C(=O)CBr</smiles>

11<smiles>O=C(CBr)c1ccccc1Cl</smiles>

12<smiles>O=C(CBr)c1ccc([N+](=O)[O-])cc1</smiles>

13<smiles>[Z7]c1ccc(C(=O)CBr)cc1</smiles>

14<smiles>[Z5]c1ccc(C(=O)CBr)cc1</smiles>

15<smiles>COc1ccccc1C(=O)CBr</smiles>

$2 \mathrm{~h}$

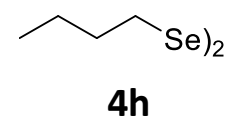

$4 a$<smiles>CCCCC[Se]c1c(-c2ccccc2)nc2ccccn12</smiles><smiles>[Si]c1nc2ccccn2c1[Se]c1ccc(Cl)cc1</smiles>

2<smiles>Fc1ccc(-c2nc3ccccn3c2[Se]c2ccccc2)cc1</smiles>

5j<smiles>Clc1ccccc1-c1nc2ccccn2c1[Se]c1ccccc1</smiles>

5k

$4 a$<smiles>O=[N+]([O-])c1ccc(-c2nc3ccccn3c2[Se]c2ccccc2)cc1</smiles>

2<smiles>Cc1ccc(-c2nc3ccccn3c2[Se]c2ccccc2)cc1</smiles>

2

$4 a$<smiles>COc1ccc(-c2nc3ccccn3c2[Se]c2ccccc2)cc1</smiles>

3

1

$4 a$<smiles>COc1ccccc1-c1nc2ccccn2c1[Se]c1ccccc1</smiles>

50<smiles>[AsH2]c1ccccc1</smiles>
6<smiles></smiles>

2 54 49 72 70 


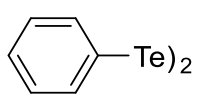

7

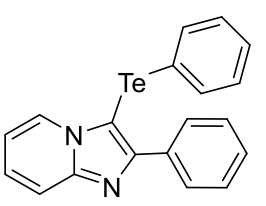

$5 q$
2

NR

${ }^{a}$ Reaction performed using $2(0.50 \mathrm{mmol}), 4(0.50 \mathrm{mmol}), \mathrm{K}_{2} \mathrm{CO}_{3}(0.75 \mathrm{mmol})$ in PEG-400 (1 mL) under US for 15-30 min. Then, diorganyl diselenide $4(0.3 \mathrm{mmol})$ and the mixture $\mathrm{CuSO}_{4} / \mathrm{KI}(1 \mathrm{mmol}$ each) were added. The reactions were monitored by TLC. NR = no reaction.

The electron-deficient diaryl diselenides $\mathbf{4 b}(\mathrm{R}=4-\mathrm{Cl}), \mathbf{4 c}(\mathrm{R}=4-\mathrm{F})$ and $\mathbf{4 d}\left(\mathrm{R}=3-\mathrm{CF}_{3}\right)$ reacted under the optimal conditions with $\mathbf{3 a}$ (generated in situ) to afford the expected products $\mathbf{5 b} \mathbf{b}-\mathbf{d} \mathbf{7 0}-90 \%$ yields. The same reactivity was showed by electron-rich diaryl diselenides $4 \mathbf{e}(\mathrm{R}=4-\mathrm{OMe})$ and $\mathbf{4 f}\left(\mathrm{R}=4-\mathrm{CH}_{3}\right)$, that delivered the respective products $\mathbf{5 e}$ and $\mathbf{5 f}$ in $73 \%$ and $54 \%$ yields (Table 4 , entries $2-6$ ). On the other hand, the bulkier dimesityl diselenide $\mathbf{4 h}$ was less reactive, due to the strong steric hindrance effect; the 3-mesitylselanylimidazo[1,2-a]pyridine $\mathbf{5}$ h was obtained in only $38 \%$ yield (Table 4 , entry 7 ). The methodology was successfully extended to the aliphatic dibutyl diselenide $4 \mathrm{~h}$, affording the product $5 \mathrm{~h}$ in $81 \%$ after 2 hours (Table 4 , entry 8).

We evaluated the scope of the reaction regarding to a range of imidazo[1,2-a]pyridines 3, prepared in situ from different 2-bromoacetophenone derivatives 2 . It was observed that the reaction is very sensitive to steric effects due to substituents in the 2-bromoacetophenone counterpart 2 . This low reactivity was not observed in the synthesis of the respective imidazo[1,2-a]pyridines $3 \mathbf{d}(\mathrm{R}=2-\mathrm{Cl})$ and $3 \mathrm{~h}(\mathrm{R}=2-\mathrm{OMe})$; therefore it cannot be attributed to this step of the one-pot synthesis. For instance, the ortho-chloro-substituted acetophenone $\mathbf{2 d}$ gave only $5 \%$ yield of the expected product $\mathbf{5 k}$, while the reaction using ortho-methoxy derivative $\mathbf{2 h}$ failed completely (Table 4, entries 11 and 15). The presence of electron-withdrawing group at the para-position in the phenyl ring of the 2-bromoacetophenone negatively affects the reaction, and products $5 \mathbf{i}(R=4-C l), 5 \mathbf{j}(R=$ $4-\mathrm{F})$ and $5 \mathrm{I}\left(\mathrm{R}=4-\mathrm{NO}_{2}\right)$ were obtained in $54 \%, 57 \%$ and $49 \%$ yields, respectively (Table 4, entries 9, 10 and 12$)$. These yields are slightly lower than those observed for 2-bromoacetophenone derivatives $2 f\left(R=4-\mathrm{CH}_{3}\right)$ and $\mathbf{2 g}(\mathrm{R}=4-\mathrm{OMe})$, which afforded the respective selenylated products $\mathbf{5 m}$ and $\mathbf{5 n}$ in $72 \%$ and $70 \%$ yields (Table 4 , entries 13 and 14). Besides the diorganyl diselenides 4, some reactions were also conducted using diphenyl disulfide 6 and diphenyl ditelluride 7 as chalcogen sources. Diphenyl disulfide 6 led to the formation of 3phenylsulfanyl-imidazo[1,2-a]pyridine $5 p$ in $54 \%$ yield. The ditelluride analogue 7 , however, did not react under the optimal reaction conditions (Table 4, entries 16 and 17). Interesting, the reactions to obtain products $\mathbf{5 c}$ and $\mathbf{5 n}$ were interrupted after $1 \mathrm{~h}$ of sonication, once it was observed decomposition of the products after a longer reaction time (Table 4, entries 3 and 14).

To investigate the possible mechanism involved in this reaction, some control experiments were performed, as depicted in Scheme 2. In order to rule out the hypothesis that the reaction could proceed through a radical mechanism, we performed the reaction under the standard conditions but in the presence of the radical scavenger 2,2,6,6-tetramethyl-1-piperidinyloxy (TEMPO) (Scheme 2-A). After $2 \mathrm{~h}$ of reaction, the product 5 a was obtained in $92 \%$ yield, hinting that a radical pathway is not involved in the reaction. In addition, and according to the conditions described by Brotherton and coworkers, ${ }^{43} \mathrm{KI}$ is believed to react with $\mathrm{CuSO}_{4}$ to generate $\mathrm{K}_{2} \mathrm{SO}_{4}$ and $\mathrm{Cul}_{2}$. Copper(II) iodide is very unstable and disproportionates to Cul and $\mathrm{I}_{2}$ (Scheme 2-B). We believe that these transformations could be happening in a similar way under the sonication process. Plausibly, both iodine and copper(I) iodide could be responsible for generate electrophilic species of selenium, as demonstrated by the results from Table 3, entries 4 and 6. Following, two additional control 
reactions were performed to investigate the possible formation of $R^{2} \mathrm{Se} X(X=$ halogen) in the reaction medium and the influence of the generated copper salts in the reactivity (Scheme 2-C). Firstly, the commercially available phenylselanyl bromide 8 was used instead of $\mathrm{PhSeSePh} / \mathrm{CuSO}_{4} / \mathrm{KI}$ under the standard US conditions, giving the product $5 \mathrm{a}$ in $82 \%$ yield. Then, to investigate the possible participation of the copper salts present in the reaction media, $\mathrm{CuBr}$ was joined to the reagents. After $2 \mathrm{~h}$ of sonication, the reaction exhibited virtually the same efficiency, indicating that the halogenated species of selenium (Scheme 3, intermediate $\mathbf{B}$ ) is the main active selenium species in the present protocol.

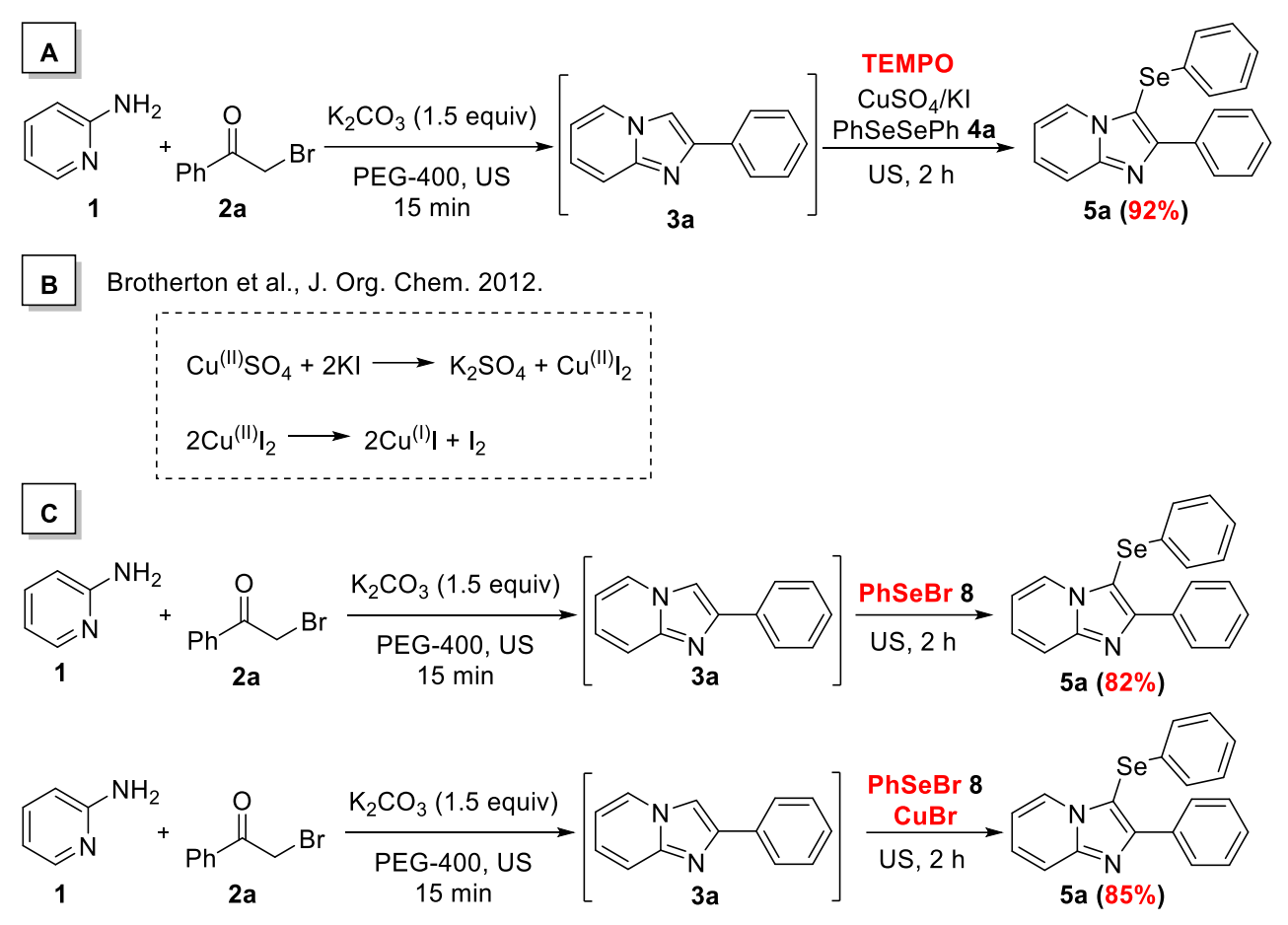

Scheme 2. Control experiments.

In this way, according to the results obtained and with the support of the literature, we can propose the following mechanism for the formation of the selenylated product $\mathbf{5}$ by the one-pot reaction (Scheme 3). Initially, 2-aminopyridine $\mathbf{1}$ nucleophilicaly attacks 2-bromoacetophenone $\mathbf{2}$ to generate the pyridinium intermediate $\mathbf{A}$. Then, intermediate $\mathbf{A}$ undergoes an intramolecular attack of the $\mathrm{NH}_{2}$ to produce imidazo[1,2a]pyridine 3, with water release. In the next step, molecular iodine, formed in the medium, ${ }^{43,44}$ reacts with diorganyl diselenide $\mathbf{4}$ to form the electrophilic species of selenium B. Finally, B undergoes a nucleophilic attack by an electron pair of imidazo[1,2-a]pyridine $\mathbf{3}$ to afford intermediate $\mathbf{C}$, that releases a proton to afford the product 5 . 


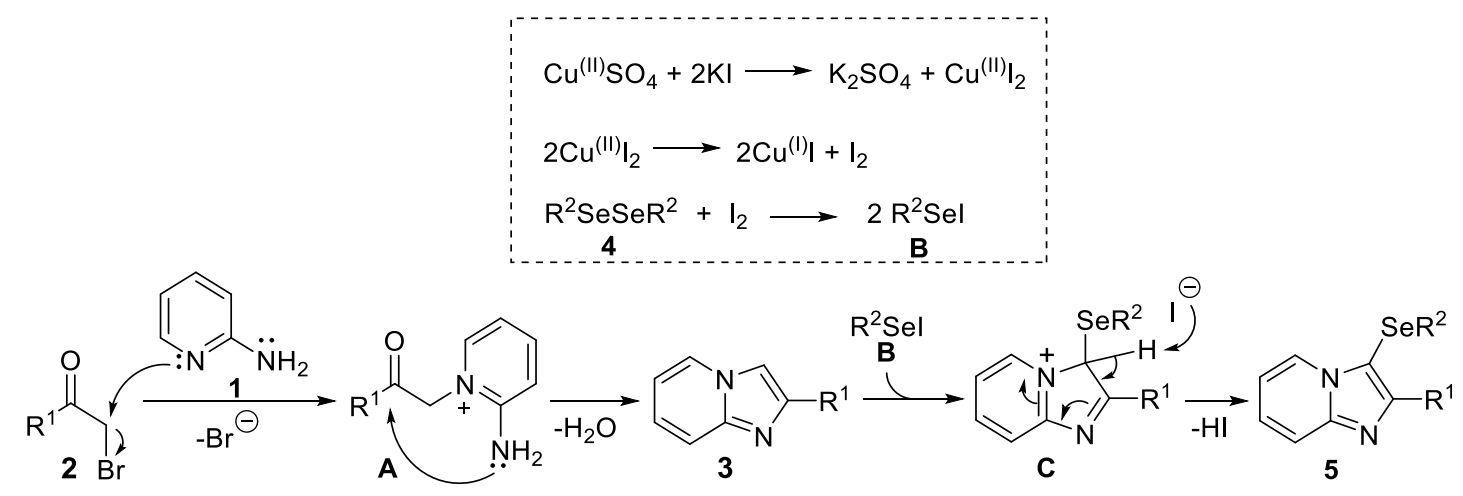

Scheme 3. Plausible mechanism.

\section{Conclusions}

In conclusion, a series of imidazo[1,2-a]pyridines were synthesized via ultrasound-mediated reaction of 2aminopyridine with 2-bromoacetophenone derivatives. This strategy was efficiently extended to the one-pot synthesis of 3-selanylimidazo[1,2-a]pyridines, by the reaction of imidazo[1,2-a]pyridines formed in situ with diorganyl diselenide in the presence of copper(II) sulfate/potassium iodide under sonication. The advantages in using ultrasound include short reaction times, mild reaction conditions and ease of operation. All the reactions were conducted in air atmosphere using PEG-400 as a non-toxic and environmentally benign solvent.

\section{Experimental Section}

General. Reactions were monitored by TLC which was carried out on Merck silica gel (60 F 254 ) by using UV light as visualizing agent and $5 \%$ vanillin in $10 \% \mathrm{H}_{2} \mathrm{SO}_{4}$ and heat as developing agents. Column chromatography was performed using silica gel (70-230 mesh). Proton nuclear magnetic resonance spectra ( ${ }^{1} \mathrm{H}$ NMR) were obtained at $400 \mathrm{MHz}$ on Bruker DPX 400 spectrometer. Spectra were recorded in $\mathrm{CDCl}_{3}$ and $\mathrm{CDCl}_{3} / \mathrm{DMSO}-d_{6}$ solutions. Chemical shifts are reported in ppm, referenced to tetramethylsilane (TMS) as the external reference. Proton coupling patterns are described as singlet $(\mathrm{s})$, doublet $(\mathrm{d})$, triplet $(\mathrm{t})$, double doublet (dd), double triplet (dt) and multiplet $(\mathrm{m})$. Coupling constants $(J)$ are reported in Hertz. Carbon-13 nuclear magnetic resonance spectra $\left({ }^{13} \mathrm{C} N M R\right)$ were obtained at $100 \mathrm{MHz}$ on a Bruker DPX 400 spectrometer. Chemical shifts are reported in ppm, referenced to the solvent peak of $\mathrm{CDCl}_{3}$. Low-resolution mass spectra (MS) were obtained with a Shimadzu GC-MS-QP2010P mass spectrometer. GC analys is were conducted on a RESTEC RTX-5MS capillary column (30 $\mathrm{m}, 0.25 \mathrm{~mm}$ id, $0.25 \mu \mathrm{m}$ film thickness) using the products dissolved in ethyl acetate with the following conditions: Injected sample volume was $1.0 \mu \mathrm{L}$; He constant flow, $54.1 \mathrm{~mL} / \mathrm{min}$; initial inlet temperature, $40{ }^{\circ} \mathrm{C}$ ramped to $72{ }^{\circ} \mathrm{C}$ at $10{ }^{\circ} \mathrm{C} / \mathrm{min}$ followed by a $5{ }^{\circ} \mathrm{C} / \mathrm{min}$ ramp to $100{ }^{\circ} \mathrm{C}$ (held for $10 \mathrm{~min}$ ) and $10{ }^{\circ} \mathrm{C} / \mathrm{min}$ to $280{ }^{\circ} \mathrm{C}$ and held for $20 \mathrm{~min}$ (total run time: $56.8 \mathrm{~min}$ ). The ultrasound-promoted reactions were performed using a Cole Parmer-ultrasonic processor Model CPX 130, with a maximum power of $130 \mathrm{~W}$, operating at amplitude of $60 \%$ and a frequency of $20 \mathrm{kHz}$. The temperature of the reaction under US was monitored using an Incoterm digital infrared thermometer Model Infraterm (Brazil). High-resolution mass spectra (HRMS) were obtained for all compounds on a LTQ Orbitrap Discovery mass spectrometer (Thermo Fisher Scientific). This hybrid system meets the LTQ XL linear ion trap mass spectrometer and an Orbitrap mass analyzer. The experiments were 
performed via direct infusion of sample (flow: $10 \mu \mathrm{L} / \mathrm{min}$ ) in the positive-ion mode using electrospray ionization. Elemental composition calculations for comparison were executed using the specific tool included in the Qual Browser module of Xcalibur (Thermo Fisher Scientific, release 2.0.7) software. Melting point (mp) values were measured in a Marte PFD III instrument with a $0.1^{\circ} \mathrm{C}$ precision.

General procedure for the synthesis 2-arylimidazo[1,2-a]pyridines 3a-h. To a $10 \mathrm{~mL}$ vial was added a mixture of 2-aminopyridine 1 (0.5 mmol), 2-bromoacetophenone derivative $2(0.5 \mathrm{mmol})$ and $\mathrm{K}_{2} \mathrm{CO}_{3}(0.103 \mathrm{~g}, 0.75$ $\mathrm{mmol}$ ) in PEG-400 (1 mL). Then, the ultrasonic probe was introduced in the flask and the mixture was sonicated at $20 \mathrm{kHz}$ and $60 \%$ of amplitude. The progress of the reaction was monitored by TLC and after the time indicated in Table 2, the reaction mixture was received in water $(10 \mathrm{~mL})$, extracted with ethyl acetate ( $3 \mathrm{x}$ $5 \mathrm{~mL}$ ), dried over $\mathrm{MgSO}_{4}$ and concentrated under vacuum. The residue was purified by column chromatography using silica gel and a mixture of ethyl acetate/hexanes as the eluent.

2-Phenylimidazo[1,2-a]pyridine (3a). White solid, mp 137-139 ${ }^{\circ} \mathrm{C}$; lit. ${ }^{45} 136-137{ }^{\circ} \mathrm{C}$. Yield: $0.091 \mathrm{~g}$ (94\%); NMR ${ }^{1} \mathrm{H}\left(\mathrm{CDCl}_{3}, 400 \mathrm{MHz}\right): \delta=8.1(\mathrm{~d}, J 6.8 \mathrm{~Hz}, 1 \mathrm{H}), 8.0-7.9(\mathrm{~m}, 2 \mathrm{H}), 7.9(\mathrm{~s}, 1 \mathrm{H}), 7.7(\mathrm{~d}, J 9.1 \mathrm{~Hz}, 1 \mathrm{H}), 7.5(\mathrm{t}, J 7.5 \mathrm{~Hz}$, $2 \mathrm{H}), 7.4-7.3(\mathrm{~m}, 1 \mathrm{H}), 7.2-7.1(\mathrm{~m}, 1 \mathrm{H}), 6.8(\mathrm{dt}, J 6.8,1.2,0.1 \mathrm{~Hz}, 1 \mathrm{H}) . \mathrm{NMR}^{13} \mathrm{C}\left(\mathrm{CDCl}_{3}, 100 \mathrm{MHz}\right): \delta=145.7$, 145.6, 133.6, 128.8, 128.0, 126.1, 125.6, 124.8, 117.5, 112.5, 108.1 .MS: $m / z$ (rel. int.) 194 (100), 167 (7.5), 116 (3.3), 78 (25).

2-(4-Chlorophenyl)imidazo[1,2-a]pyridine (3b). White solid, mp 213-115 ${ }^{\circ} \mathrm{C}$; Lit.: ${ }^{1}$ 207-209 ${ }^{\circ} \mathrm{C}$. Yield: $0.088 \mathrm{~g}$ (78\%); $\mathrm{NMR}^{1} \mathrm{H}\left(\mathrm{CDCl}_{3} / \mathrm{DMSO}-d_{6}, 400 \mathrm{MHz}\right): \delta 8.4$ (t, J $\left.5.6 \mathrm{~Hz}, 1 \mathrm{H}\right), 8.2(\mathrm{~d}, J 7.7 \mathrm{~Hz}, 1 \mathrm{H}), 7.9(\mathrm{dd}, J 11.6,7.9 \mathrm{~Hz}$, 2H), 7.5 (t, J $10.0 \mathrm{~Hz}, 1 \mathrm{H}$ ), 7.4 (dd, J 11.4, $7.8 \mathrm{~Hz}, 2 \mathrm{H}$ ), $7.2(\mathrm{dt}, J 10.3,5.1 \mathrm{~Hz}, 1 \mathrm{H}$ ), 6.8 (q, J 6.0, 5.0 Hz, 1H). NMR ${ }^{13} \mathrm{C}\left(\mathrm{CDCl}_{3} / \mathrm{DMSO}-d_{6}, 100 \mathrm{MHz}\right): \delta=143.6,142.0,131.2,131.0,127.1,125.6,125.0,123.6,115.1,110.9,107.6$. MS: $m / z$ (rel. int.) 228 (100), 193 (13), 115 (3.5), 78 (38).

2-(4-Fluorophenyl)imidazo[1,2-a]pyridine (3c). White solid, mp 164-165; Lit..21 163.1-163.4. Yield: $0.093 \mathrm{~g}$ (88\%); $\mathrm{NMR}^{1} \mathrm{H}\left(\mathrm{CDCl}_{3}, 400 \mathrm{MHz}\right): \delta=8.1(\mathrm{dt}, J 6.8,1.2 \mathrm{~Hz}, 1 \mathrm{H}), 7.9-7.9(\mathrm{~m}, 2 \mathrm{H}), 7.8(\mathrm{~s}, 1 \mathrm{H}), 7.6(\mathrm{dq}, J 9.1,1.0$ $\mathrm{Hz}, 1 \mathrm{H}), 7.2-7.1(\mathrm{~m}, 3 \mathrm{H}), 6.7(\mathrm{td}, J 6.7,1.2 \mathrm{~Hz}, 1 \mathrm{H}) . \mathrm{NMR}{ }^{13} \mathrm{C}\left(\mathrm{CDCl}_{3}, 100 \mathrm{MHz}\right): \delta=162.6(\mathrm{~d}, J 246.6 \mathrm{~Hz}), 145.6$, $144.8,129.8,127.6$ (d, J 8.5 Hz), 125.5, 124.8, 117.3, 115.6 (d, J 21.4 Hz), 112.4, 107.7. MS: $m / z$ (rel. int.) 212 (100), 193 (1.9), 96 (3.5), $78(36)$.

2-(2-Chlorophenyl)imidazo[1,2-a]pyridine (3d). White solid, mp 78.6-79.9 ${ }^{\circ} \mathrm{C}$; Yield: $0.090 \mathrm{~g}(79 \%) ; \mathrm{NMR}{ }^{1} \mathrm{H}$ $\left(\mathrm{CDCl}_{3}, 400 \mathrm{MHz}\right): \delta=8.4-8.3(\mathrm{~m}, 2 \mathrm{H}), 8.1(\mathrm{dt}, J 6.8,1.2 \mathrm{~Hz}, 1 \mathrm{H}), 7.6(\mathrm{dq}, J 9.2,1.0 \mathrm{~Hz}, 1 \mathrm{H}), 7.5(\mathrm{dd}, J 8.0 ; 1.3$ $\mathrm{Hz}, 1 \mathrm{H}), 7.4(\mathrm{td}, J 7.6,1.3 \mathrm{~Hz}, 1 \mathrm{H}), 7.3-7.2(\mathrm{~m}, 1 \mathrm{H}), 7.2(\mathrm{ddd}, J 9.2,6.7,1.3 \mathrm{~Hz}, 1 \mathrm{H}), 6.8(\mathrm{td}, J 6.8,1.2 \mathrm{~Hz}, 1 \mathrm{H})$. $\mathrm{NMR}{ }^{13} \mathrm{C}\left(\mathrm{CDCl}_{3}, 100 \mathrm{MHz}\right): \delta=144.5,141.8,132.3,131.7,131.0,130.3,128.6,127.1,125.8,124.9,117.5$, 112.5 .MS: $m / z$ (rel. int.) 228 (100), 193 (14.6), 115 (2.8), 78 (21).

2-(4-Nitrophenyl)imidazo[1,2-a]pyridine (3e). Yellow solid, mp 264-266 ${ }^{\circ} \mathrm{C}$ Lit.: 46 265-267 ${ }^{\circ} \mathrm{C}$; Yield: $0.0956 \mathrm{~g}$ (80\%); NMR ${ }^{1} \mathrm{H}$ (DMSO-d, $\left.400 \mathrm{MHz}\right): \delta=8.7-8.5(\mathrm{~m}, 2 \mathrm{H}), 8.3(\mathrm{~d}, J 8.9 \mathrm{~Hz}, 2 \mathrm{H}), 8.2(\mathrm{~d}, J 8.9 \mathrm{~Hz}, 2 \mathrm{H}), 7.6(\mathrm{~d}, J 9.1$ $\mathrm{Hz}, 1 \mathrm{H}), 7.3(\mathrm{t}, J 7.9 \mathrm{~Hz}, 1 \mathrm{H}), 6.9(\mathrm{t}, J 6.7 \mathrm{~Hz}, 1 \mathrm{H}) . \mathrm{NMR}^{13} \mathrm{C}$ (DMSO-d, $100 \mathrm{MHz}$ ): $\delta=144.8,143.6,140.4,138.8$, 125.3, 124.5, 123.9, 122.2, 115.2, 111.0, 109.7. MS: $m / z$ (rel. int.) 239 (100), 193 (57), 115 (2.3) 78 (24).

2-(p-Tolyl)imidazo[1,2-a]pyridine (3f). White solid, $\mathrm{mp} 145-146{ }^{\circ} \mathrm{C}$; Lit.: ${ }^{45} 144-145{ }^{\circ} \mathrm{C}$. Yield: 0,088 g (85\%); $\mathrm{NMR}{ }^{1} \mathrm{H}\left(\mathrm{CDCl}_{3}, 400 \mathrm{MHz}\right): \delta=8.1(\mathrm{dt}, J 6.8,1.2 \mathrm{~Hz}, 1 \mathrm{H}), 7.9-7.8(\mathrm{~m}, 3 \mathrm{H}), 7.6(\mathrm{dq}, J 9.1,1.0 \mathrm{~Hz}, 1 \mathrm{H}), 7.3-7.2$ $(\mathrm{m}, 2 \mathrm{H}), 7.2(\mathrm{ddd}, J 9.1,6.8,1.3 \mathrm{~Hz}, 1 \mathrm{H}), 6.8(\mathrm{td}, J 6.8,1.2 \mathrm{~Hz}, 1 \mathrm{H}), 2.4(\mathrm{~s}, 3 \mathrm{H}) . \mathrm{NMR}{ }^{13} \mathrm{C}\left(\mathrm{CDCl}_{3}, 75 \mathrm{MHz}\right): \delta=$ $145.8,145.5,137.8,130.8,129.4,125.9,125.5,124.5,117.3,112.3,107.7,21.3 . \mathrm{MS}: \mathrm{m} / z$ (rel. int.) 208 (100), 193 (1.7), 91 (5.8), 78 (16).

2-(4-Methoxyphenyl)imidazo[1,2-a]pyridine (3g). Yellow solid; mp. 132-134 o C; Lit.: ${ }^{45} 135-136{ }^{\circ} \mathrm{C} ;$ Yield: 0.109 g (90\%); $\mathrm{NMR}^{1} \mathrm{H}\left(\mathrm{CDCl}_{3}, 400 \mathrm{MHz}\right): \delta=8.1(\mathrm{~d}, J 6.8 \mathrm{~Hz}, 1 \mathrm{H}), 7.9(\mathrm{~d}, J 8.9 \mathrm{~Hz}, 2 \mathrm{H}), 7.7(\mathrm{~d}, J 2.3 \mathrm{~Hz}, 1 \mathrm{H}), 7.6(\mathrm{~d}, J$ 
$9.1 \mathrm{~Hz}, 1 \mathrm{H}), 7.2-7.1(\mathrm{~m}, 1 \mathrm{H}), 7.0-6.9(\mathrm{~m}, 2 \mathrm{H}), 6.7$ (tq, J 6.6, $1.2 \mathrm{~Hz}, 1 \mathrm{H}), 3.8(\mathrm{~d}, J 1.1 \mathrm{~Hz}, 3 \mathrm{H}) . \mathrm{NMR}^{13} \mathrm{C}\left(\mathrm{CDCl}_{3}\right.$, $100 \mathrm{MHz}$ ): $\delta=159.5,145.5,145.5,127.2,126.3,125.4,124.4,117.1,114.1,112.2,107.2,55.2$. MS: $\mathrm{m} / \mathrm{z}$ (rel. int.) 224 (100), 209 (58), 181 (65), $78(56)$.

2-(2-Methoxyphenyl)imidazo[1,2-a]pyridine (3h). Brown solid; mp 94-96 ${ }^{\circ} \mathrm{C}$; Lit.: ${ }^{47}$ 95.5-97 ${ }^{\circ} \mathrm{C}$. Yield: $0.109 \mathrm{~g}$ (98\%); $\mathrm{NMR}^{1} \mathrm{H}\left(\mathrm{CDCl}_{3}, 400 \mathrm{MHz}\right): \delta=8.3(\mathrm{dd}, J 7.7,1.8 \mathrm{~Hz}, 1 \mathrm{H}), 8.1(\mathrm{~s}, 1 \mathrm{H}), 8.0(\mathrm{dt}, J 6.8,1.2 \mathrm{~Hz}, 1 \mathrm{H}), 7.5(\mathrm{dd}, J$ 9.1, $1.0 \mathrm{~Hz}, 1 \mathrm{H}), 7.2-7.2(\mathrm{~m}, 1 \mathrm{H}), 7.1-7.0(\mathrm{~m}, 2 \mathrm{H}), 6.9(\mathrm{dd}, J$ 8.3, $1.1 \mathrm{~Hz}, 1 \mathrm{H}), 6.6(\mathrm{td}, J$ J $6.8,1.2 \mathrm{~Hz}, 1 \mathrm{H}), 3.9(\mathrm{~s}$, 3H). $\mathrm{NMR}^{13} \mathrm{C}\left(\mathrm{CDCl}_{3}, 100 \mathrm{MHz}\right): \delta=156.8,144.3,141.1,128.9,128.7,125.6,124.5,122.3,121.0,117.2,112.5$, 112.0, 110.9, 55.4. MS: $m / z$ (rel. int.) 224 (100), 193 (1.5), 209 (54.2), 78 (21.4).

General procedure for the synthesis of 3-selanylimidazo[1,2-a]pyridines 5a-q. A mixture of 2-aminopyridine 1 (0.5 mmol), 2-bromoacetophenone derivative 2 (0.5 mmol), $\mathrm{K}_{2} \mathrm{CO}_{3}(0.103 \mathrm{~g}, 0,75 \mathrm{mmol})$ and PEG-400 (1 mL), was added to a $10 \mathrm{~mL}$ vial. Then, the ultrasonic probe was introduced in the flask and the mixture was sonicated at $20 \mathrm{kHz}$ and $60 \%$ of amplitude. The progress of the reaction was monitored by TLC as indicated in Table 2. Then diorganyldiselenide $4\left(0.3 \mathrm{mmol}\right.$ ) and $\mathrm{CuSO}_{4} / \mathrm{KI}$ (2 equiv.) were added and the reaction mixture was sonicated again at $20 \mathrm{kHz}$ and $60 \%$ of amplitude by the time indicated in Table 4 . The progress of the reaction was monitored by TLC. After that, the reaction mixture was received in water (10 $\mathrm{mL})$, extracted with ethyl acetate $(3 \times 5 \mathrm{~mL})$, dried over $\mathrm{MgSO}_{4}$ and concentrated under vacuum. The residue was purified by column chromatography using silica gel and a mixture of ethyl acetate/hexanes as the eluent.

2-Phenyl-3-(phenylselanyl)imidazo[1,2-a]pyridine (5a). Yellow solid, mp 91.1-93.1 ${ }^{\circ} \mathrm{C}$. Yield: $0.166 \mathrm{~g}(95 \%) ;{ }^{1} \mathrm{H}$ NMR $\left(\mathrm{CDCl}_{3}, 400 \mathrm{MHz}\right): \delta=\delta 8.31(\mathrm{~d}, J 6.8 \mathrm{~Hz}, 1 \mathrm{H}), 8.16(\mathrm{~d}, J 7.2 \mathrm{~Hz}, 2 \mathrm{H}), 7.69(\mathrm{~d}, J 9.0 \mathrm{~Hz}, 1 \mathrm{H}), 7.42(\mathrm{t}, J 7.5 \mathrm{~Hz}$, $2 \mathrm{H}), 7.34(\mathrm{t}, J 7.3 \mathrm{~Hz}, 1 \mathrm{H}), 7.27-7.23(\mathrm{~m}, 1 \mathrm{H}), 7.13-7.07(\mathrm{~m}, 5 \mathrm{H}), 6.78(\mathrm{t}, J 6.7 \mathrm{~Hz}, 1 \mathrm{H}) .{ }^{13} \mathrm{C} \mathrm{NMR}(\mathrm{CDCl}, 100$ $\mathrm{MHz}): \delta=151.7,147.7,133.8,130.8,129.6,128.7,128.3,128.25,128.18,126.6,126.3,125.5,117.5,112.8$, 102.9. MS: $m / z$ (rel. int.) 350 (37.5), 270 (100.0), 193 (9.8), 77 (9.9).

3-[(4-Chlorophenyl)selanyl]-2-phenylimidazo[1,2-a]pyridine (5b). White solid, mp 135.1-136.4; Yield: $0.173 \mathrm{~g}$ (90\%); ${ }^{1} \mathrm{H} \mathrm{NMR}\left(\mathrm{CDCl}_{3}, 400 \mathrm{MHz}\right): \delta=8.28(\mathrm{~d}, J 6.9 \mathrm{~Hz}, 1 \mathrm{H}), 8.15-8.13(\mathrm{~m}, 2 \mathrm{H}), 7.69(\mathrm{~d}, J 9.0 \mathrm{~Hz}, 1 \mathrm{H}), 7.42(\mathrm{t}, J$ $7.4 \mathrm{~Hz}, 2 \mathrm{H}), 7.35(\mathrm{t}, J 7.3 \mathrm{~Hz}, 1 \mathrm{H}), 7.29-7.24(\mathrm{~m}, 1 \mathrm{H}), 7.10(\mathrm{~d}, J 8.6 \mathrm{~Hz}, 2 \mathrm{H}), 6.99(\mathrm{~d}, J 8.6 \mathrm{~Hz}, 2 \mathrm{H}), 6.81(\mathrm{td}, J 6.8$,

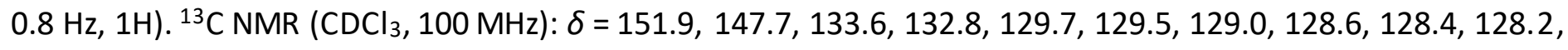
126.4, 125.3, 117.5, 113.0, 102.4. MS: $m / z$ (rel. int.) 384 (46.5), 304 (100.0), 194 (23.6), 78 (98.6).

3-[(4-Fluorophenyl)selanyl]-2-phenylimidazo[1,2-a]pyridine (5c). Yellow solid, $\mathrm{mp} 116.5-118.1^{\circ} \mathrm{C}$ Yield: 0.130 $\mathrm{g}(71 \%) ;{ }^{1} \mathrm{H} \mathrm{NMR}\left(\mathrm{CDCl}_{3}, 400 \mathrm{MHz}\right): \delta=8.31(\mathrm{~d}, J 6.8 \mathrm{~Hz}, 1 \mathrm{H}), 8.16(\mathrm{~d}, J 7.4 \mathrm{~Hz}, 2 \mathrm{H}), 7.70(\mathrm{~d}, J 9.0 \mathrm{~Hz}, 1 \mathrm{H}), 7.45-$ $7.34(\mathrm{~m}, 3 \mathrm{H}), 7.29-7.25(\mathrm{~m}, 1 \mathrm{H}), 7.07(\mathrm{dd}, J 8.5,5.3 \mathrm{~Hz}, 2 \mathrm{H}), 6.87-6.80(\mathrm{~m}, 3 \mathrm{H}) .{ }^{13} \mathrm{C} \mathrm{NMR}\left(\mathrm{CDCl}_{3}, 100 \mathrm{MHz}\right): \delta$ $=162.0\left(\mathrm{~d},{ }^{1} J_{\mathrm{C}-\mathrm{F}}=246.4 \mathrm{~Hz}\right), 151.5,147.5,133.5,130.2\left(\mathrm{~d},{ }^{3} J_{\mathrm{C}-\mathrm{F}}=7.6 \mathrm{~Hz}\right), 128.6,128.4,128.2,126.4,125.3$, $125.0\left(\mathrm{~d},{ }^{4} J_{\mathrm{C}-\mathrm{F}}=3.3 \mathrm{~Hz}\right), 117.5,116.7\left(\mathrm{~d},{ }^{2} J_{\mathrm{C}-\mathrm{F}}=21.9 \mathrm{~Hz}\right), 113.0,103.1 . \mathrm{MS}: \mathrm{m} / \mathrm{z}$ (rel. int.) 368 (44.0), 288 (100.0), 194 (11.3), 78 (75.3).

2-Phenyl-3-\{[3-(trifluoromethyl)phenyl]selanyl\}imidazo[1,2-a]pyridine (5d). Yellow solid, mp 93.1-95.7 ${ }^{\circ} \mathrm{C}$ Yield: $0.146 \mathrm{~g}(70 \%) ;{ }^{1} \mathrm{H} \mathrm{NMR}\left(\mathrm{CDCl}_{3}, 400 \mathrm{MHz}\right): \delta=8.31(\mathrm{~d}, J 6.9 \mathrm{~Hz}, 1 \mathrm{H}), 8.12(\mathrm{~d}, J 7.2 \mathrm{~Hz}, 2 \mathrm{H}), 7.74(\mathrm{~d}, J$ $9.0 \mathrm{~Hz}, 1 \mathrm{H}), 7.48-7.30(\mathrm{~m}, 6 \mathrm{H}), 7.22(\mathrm{t}, J 7.8 \mathrm{~Hz}, 1 \mathrm{H}), 7.10(\mathrm{~d}, J 7.9 \mathrm{~Hz}, 1 \mathrm{H}), 6.89-6.85(\mathrm{~m}, 1 \mathrm{H}) ;{ }^{13} \mathrm{C}(\mathrm{CDCl}$, $100 \mathrm{MHz}): \delta=152.2,147.8,133.3,132.3,131.9\left(\mathrm{q},{ }^{2} \mathrm{~J}_{\mathrm{C}-\mathrm{F}}=32.5 \mathrm{~Hz}\right), 131.1,130.0,128.7,128.6,128.3$, 126.8, 125.3, $124.9\left(\mathrm{q},{ }^{3} J_{\mathrm{C}-\mathrm{F}}=3.8 \mathrm{~Hz}\right), 123.5\left(\mathrm{q},{ }^{3} J_{\mathrm{C}-\mathrm{F}}=3.6 \mathrm{~Hz}\right), 123.0\left(\mathrm{q},{ }^{1} \mathrm{~J}_{\mathrm{C}-\mathrm{F}}=273.4 \mathrm{~Hz}\right), 117.6,113.3$, 101.8. MS: $m / z$ (rel. int.) 418 (50.8), 338 (100.0), 193 (11.7), 78 (79.9).

3-[(4-Methoxyphenyl)selanyl]-2-phenylimidazo[1,2-a]pyridine (5e). Yellow oil, yield: $0.138 \mathrm{~g}(73 \%) ;{ }^{1} \mathrm{H} \mathrm{NMR}$ $\left(\mathrm{CDCl}_{3}, 400 \mathrm{MHz}\right): \delta=8.36(\mathrm{~d}, J 6.7 \mathrm{~Hz}, 1 \mathrm{H}), 8.20(\mathrm{~d}, J 8.1 \mathrm{~Hz}, 2 \mathrm{H}), 7.65(\mathrm{~d}, J 8.8 \mathrm{~Hz}, 1 \mathrm{H}), 7.42(\mathrm{t}, J 7.5 \mathrm{~Hz}, 2 \mathrm{H})$, $7.36-7.32(\mathrm{~m}, 1 \mathrm{H}), 7.23-7.19(\mathrm{~m}, 1 \mathrm{H}), 7.07(\mathrm{~d}, J 8.5 \mathrm{~Hz}, 2 \mathrm{H}), 6.77(\mathrm{t}, J 6.8 \mathrm{~Hz}, 1 \mathrm{H}), 6.68(\mathrm{~d}, J 8.5 \mathrm{~Hz}, 2 \mathrm{H}), 3.65$ 
(s, 3H); ${ }^{13} \mathrm{C}\left(\mathrm{CDCl}_{3}, 100 \mathrm{MHz}\right): \delta=159.1,151.2,147.4,134.0,130.8,128.8,128.2,128.1,126.0,125.5,120.5$, 117.4, 115.4, 112.7, 104.1, 55.2. MS: $m / z$ (rel. int.) 380 (21.3), 273 (61.4), 194 (100.0), 78 (70.5).

2-Phenyl-3-(p-tolylselanyl)imidazo[1,2-a]pyridine (5f). White solid, mp 126.5-127.8 ${ }^{\circ} \mathrm{C}$. Yield: $0.098 \mathrm{~g}(54 \%)$; NMR ${ }^{1} \mathrm{H}\left(\mathrm{CDCl}_{3}, 400 \mathrm{MHz}\right): \delta=8.4(\mathrm{~d}, J 6.9 \mathrm{~Hz}, 1 \mathrm{H}), 8.2-8.1(\mathrm{~m}, 2 \mathrm{H}), 7.7(\mathrm{dt}, J 9.1,1.1 \mathrm{~Hz}, 1 \mathrm{H}), 7.5-7.4(\mathrm{~m}, 2 \mathrm{H})$, $7.4-7.3(\mathrm{~m}, 2 \mathrm{H}), 7.1-7.0(\mathrm{~m}, 4 \mathrm{H}), 6.8(\mathrm{td}, J 6.8,1.1 \mathrm{~Hz}, 1 \mathrm{H}), 2.3(\mathrm{~s}, 3 \mathrm{H}) . \mathrm{NMR}{ }^{13} \mathrm{C}\left(\mathrm{CDCl}_{3}, 100 \mathrm{MHz}\right): \delta=151.5$, 147.6, 136.7, 133.8, 130.4, 128.8, 128.5, 128.4, 128.3, 126.9, 126.4, 125.6, 117.5, 112.9, 29.7, 20.9. MS: $\mathrm{m} / \mathrm{z}$ (rel. int.) 364 (33.9), 284 (100), 193 (5.3), 78 (65.3). HRMS: Calcd. for $\mathrm{C}_{20} \mathrm{H}_{16} \mathrm{~N}_{2} \mathrm{Se}[\mathrm{M}+\mathrm{H}]^{+}$: 365.0552 found: 365.0551.

3-(Mesitylselanyl)-2-phenylimidazo[1,2-a]pyridine (5g). White solid, $\mathrm{mp} 49.1-51.6{ }^{\circ} \mathrm{C}$. Yield: $0.074 \mathrm{~g}(38 \%)$; NMR ${ }^{1} \mathrm{H}\left(\mathrm{CDCl}_{3}, 400 \mathrm{MHz}\right): \delta=8.1-8.0(\mathrm{~m}, 3 \mathrm{H}), 7.7(\mathrm{dt}, J 9.0,1.2 \mathrm{~Hz}, 1 \mathrm{H}), 7.5-7.4(\mathrm{~m}, 2 \mathrm{H}), 7.4-7.4(\mathrm{~m}, 1 \mathrm{H})$, $7.2-7.2(\mathrm{~m}, 1 \mathrm{H}), 6.8-6.7(\mathrm{~m}, 3 \mathrm{H}), 2.2(\mathrm{~s}, 6 \mathrm{H}), 2.2(\mathrm{~s}, 3 \mathrm{H}) ;{ }^{13} \mathrm{C}\left(\mathrm{CDCl}_{3}, 100 \mathrm{MHz}\right): \delta=150.0,146.8,141.3,138.0$, 134.1, 129.4, 129.0, 128.1, 128.1, 126.2, 125.4, 125.4, 117.3, 112.6, 104.6, 23.6, 20.7 . MS: $\mathrm{m} / z$ (rel. int.) 392 (28), 312 (100), 193 (8.2), 78 (39). HRMS: Calcd. for $\mathrm{C}_{22} \mathrm{H}_{20} \mathrm{~N}_{2} \mathrm{Se}$ : [M+H] $]^{+}: 393.0865$ found: 393.0865.

3-(Butylselanyl)-2-phenylimidazo[1,2-a]pyridine (5h). Brown oil. Yield: $0.139 \mathrm{~g}(81 \%) ;{ }^{1} \mathrm{H} \mathrm{NMR}^{(\mathrm{CDCl}} 3,400$ $\mathrm{MHz}): \delta=8.52(\mathrm{~d}, J 6.8 \mathrm{~Hz}, 1 \mathrm{H}), 8.23(\mathrm{~d}, J 7.5 \mathrm{~Hz}, 2 \mathrm{H}), 7.66(\mathrm{~d}, J 9.0 \mathrm{~Hz}, 1 \mathrm{H}), 7.45(\mathrm{t}, J 7.6 \mathrm{~Hz}, 2 \mathrm{H}), 7.35(\mathrm{t}, J 7.3$ $\mathrm{Hz}, 1 \mathrm{H}$ ), $7.26-7.22(\mathrm{~m}, 1 \mathrm{H}), 6.87(\mathrm{t}, J 6.7 \mathrm{~Hz}, 1 \mathrm{H}), 2.64(\mathrm{t}, J 7.3 \mathrm{~Hz}, 2 \mathrm{H}), 1.45$ (quint, J 7.2 Hz, 2H), 1.27 (sext, J $7.3 \mathrm{~Hz}, 2 \mathrm{H}), 0.74(\mathrm{t}, J 7.3 \mathrm{~Hz}, 3 \mathrm{H}) .{ }^{13} \mathrm{CNMR}\left(\mathrm{CDCl}_{3}, 100 \mathrm{MHz}\right): \delta=150.1,147.0,134.0,128.6,128.0,127.9,125.7$, 125.4, 117.3, 112.5, 104.2, 31.9, 29.1, 22.5, 13.3.MS: m/z (rel. int.) 330 (44.0), 288 (100.0), 194 (11.3), 78 (75.3).

2-(4-Chlorophenyl)-3-(phenylselanyl)imidazo[1,2-a]pyridine (5i). Yellow solid, $\mathrm{mp} 81.1-83.4^{\circ} \mathrm{C}$; Yield: 0,103 g (54\%); $\mathrm{NMR}^{1} \mathrm{H}\left(\mathrm{CDCl}_{3}, 400 \mathrm{MHz}\right): \delta=8.4(\mathrm{dt}, J 6.9,1.2 \mathrm{~Hz}, 1 \mathrm{H}), 8.2-8.1(\mathrm{~m}, 2 \mathrm{H}), 7.7(\mathrm{dt}, J 9.0,1.1 \mathrm{~Hz}, 1 \mathrm{H}), 7.4$ $-7.4(\mathrm{~m}, 2 \mathrm{H}), 7.4-7.3(\mathrm{~m}, 1 \mathrm{H}), 7.2-7.1(\mathrm{~m}, 3 \mathrm{H}), 7.1-7.1(\mathrm{~m}, 2 \mathrm{H}), 6.9(\mathrm{td}, J 6.8,1.2 \mathrm{~Hz}, 1 \mathrm{H}) . \mathrm{NMR}^{13} \mathrm{C}(\mathrm{CDCl} 3$, $100 \mathrm{MHz}): \delta=150.6,147.8,134.5,132.3,130.6,130.0,129.8,128.6,128.2,126.8,126.7,125.6,117.5,113.2$, 103.0. MS: $m / z$ (rel. int.) 384 (41.8), 304 (100.0), 193 (1.8), 78 (83.8).

2-(4-Fluorophenyl)-3-(phenylselanyl)imidazo[1,2-a]pyridine (5j). Yellow solid, $\mathrm{mp} 99.5-101.3{ }^{\circ} \mathrm{C}$ Yield: $0.105 \mathrm{~g}$ (57\%); ${ }^{1} \mathrm{H} \mathrm{NMR}\left(\mathrm{CDCl}_{3}, 400 \mathrm{MHz}\right): \delta=8.36(\mathrm{dt}, J 6.9,1.1 \mathrm{~Hz}, 1 \mathrm{H}), 8.21-8.16(\mathrm{~m}, 2 \mathrm{H}), 7.71(\mathrm{dt}, J 9.0,1.1 \mathrm{~Hz}, 1 \mathrm{H})$, $7.33-7.28(\mathrm{~m}, 1 \mathrm{H}), 7.20-7.10(\mathrm{~m}, 7 \mathrm{H}), 6.85(\mathrm{td}, J 6.8,1.2 \mathrm{~Hz}, 1 \mathrm{H}) .{ }^{13} \mathrm{C} \mathrm{NMR}\left(\mathrm{CDCl}_{3}, 100 \mathrm{MHz}\right): \delta=163.0\left(\mathrm{~d},{ }^{1} \mathrm{~J}_{\mathrm{C}-\mathrm{F}}\right.$ $=248.1 \mathrm{~Hz}), 150.8,147.7,130.7,130.5\left(\mathrm{~d},{ }^{3} J_{\mathrm{C}-\mathrm{F}}=8.1 \mathrm{~Hz}\right), 130.0\left(\mathrm{~d},{ }^{4} \mathrm{~J}_{\mathrm{C}-\mathrm{F}}=3.2 \mathrm{~Hz}\right), 129.7,128.2,126.7,126.4$, 125.5, 117.4, 115.2 (d, $\left.{ }^{2} J_{C-F}=21.3 \mathrm{~Hz}\right), 113.0,102.7 . \mathrm{MS}: m / z$ (rel. int.) 368 (35.5), 288 (100.0), 211 (7.5), 78 (77.2).

2-(4-Nitrophenyl)-3-(phenylselanyl)imidazo[1,2-a]pyridine (5I). Yellow solid, $\mathrm{mp} 154.4-156.4{ }^{\circ} \mathrm{C}$. Yield: 0,0967 g (49\%); $\mathrm{NMR}^{1} \mathrm{H}\left(\mathrm{CDCl}_{3}, 400 \mathrm{MHz}\right): \delta=8.4-8.3(\mathrm{~m}, 3 \mathrm{H}), 8.2-8.1(\mathrm{~m}, 2 \mathrm{H}), 7.6(\mathrm{dt}, J 9.0,1.1 \mathrm{~Hz}, 1 \mathrm{H}), 7.3-7.2$ $(\mathrm{m}, 1 \mathrm{H}), 7.1-7.1(\mathrm{~m}, 3 \mathrm{H}), 7.1-7.0(\mathrm{~m}, 2 \mathrm{H}), 6.8(\mathrm{td}, J 6.8,1.2 \mathrm{~Hz}, 1 \mathrm{H}) . \mathrm{NMR}{ }^{13} \mathrm{C}\left(\mathrm{CDCl}_{3}, 100 \mathrm{MHz}\right): \delta=148.9$, 147.9, 147.5, 140.2, 130.1, 129.9, 129.2, 128.3, 127.2, 127.1, 125.7, 123.5, 117.8, 113.6, 104.6. MS: $\mathrm{m} / \mathrm{z}$ (rel. int.) 395 (16.5), 315 (69), 193 (2.8), 78 (100). HRMS: Calcd. For $\mathrm{C}_{19} \mathrm{H}_{14} \mathrm{~N}_{3} \mathrm{O}_{2} \mathrm{Se}:[\mathrm{M}+\mathrm{H}]^{+}: 396.0246$ found: 396.0380 .

3-(Phenylselanyl)-2-(p-tolyl)imidazo[1,2-a]pyridine (5m). White solid, mp 65-66 ${ }^{\circ} \mathrm{C}$; Yield: $0.131 \mathrm{~g}(72 \%)$; NMR ${ }^{1} \mathrm{H}\left(\mathrm{CDCl}_{3}, 400 \mathrm{MHz}\right): \delta=8.4(\mathrm{dt}, J 6.8,1.2 \mathrm{~Hz}, 1 \mathrm{H}), 8.1(\mathrm{~d}, J 8.2 \mathrm{~Hz}, 2 \mathrm{H}), 7.7(\mathrm{~d}, J 9.0 \mathrm{~Hz}, 1 \mathrm{H}), 7.4-7.2(\mathrm{~m}, 3 \mathrm{H})$, $7.2-7.2(\mathrm{~m}, 3 \mathrm{H}), 7.1(\mathrm{dt}, J 6.8,2.4 \mathrm{~Hz}, 2 \mathrm{H}), 6.9(\mathrm{td}, J 6.8,1.2 \mathrm{~Hz}, 1 \mathrm{H}), 2.4(\mathrm{~s}, 3 \mathrm{H}) . \mathrm{NMR}{ }^{13} \mathrm{C}(\mathrm{CDCl}, 100 \mathrm{MHz}): \delta=$ $151.8,147.6,138.3,130.9,130.8,129.6,129.0,128.5,128.1,126.6,126.3,125.5,117.3,112.8,102.4,21.3$ .MS: $m / z$ (rel. int.) 364 (34.2), 284 (100), 193 (1.1), 78 (64.3).

2-(4-Methoxyphenyl)-3-(phenylselanyl)imidazo[1,2-a]pyridine (5n). Yellow oil, yield: $0.133 \mathrm{~g}(70 \%) ;{ }^{1} \mathrm{H} \mathrm{NMR}$ $\left(\mathrm{CDCl}_{3}, 400 \mathrm{MHz}\right): \delta=8.30(\mathrm{~d}, J 6.8 \mathrm{~Hz}, 1 \mathrm{H}), 8.13(\mathrm{~d}, J 8.8 \mathrm{~Hz}, 2 \mathrm{H}), 7.67(\mathrm{~d}, J 9.0 \mathrm{~Hz}, 1 \mathrm{H}), 7.26-7.22(\mathrm{~m}, 1 \mathrm{H})$, 
$7.16-7.07(\mathrm{~m}, 5 \mathrm{H}), 6.95(\mathrm{~d}, J 8.8 \mathrm{~Hz}, 2 \mathrm{H}), 6.79-6.75(\mathrm{~m}, 1 \mathrm{H}), 3.80(\mathrm{~s}, 3 \mathrm{H}) .{ }^{13} \mathrm{C} \mathrm{NMR}\left(\mathrm{CDCl}_{3}, 100 \mathrm{MHz}\right): \delta=$ $159.8,151.6,147.6,130.9,129.9,129.5,128.1,126.5,126.3,126.2,125.4,117.2,113.7,112.7,101.9$, 55.1.MS: $m / z$ (rel. int.) 380 (32.9), 300 (100.0), 150 (4.3), 78 (45.6).

2-Phenyl-3-(phenylthio)imidazo[1,2-a]pyridine (5p). White solid, mp 106-108 ${ }^{\circ} \mathrm{C}$; Yield: $0.081 \mathrm{~g}(54 \%) ; \mathrm{NMR}{ }^{1} \mathrm{H}$ $\left(\mathrm{CDCl}_{3}, 400 \mathrm{MHz}\right): \delta=8.3-8.2(\mathrm{~m}, 3 \mathrm{H}), 7.8(\mathrm{dt}, J$ 9.0, $1.1 \mathrm{~Hz}, 1 \mathrm{H}), 7.5-7.1(\mathrm{~m}, 7 \mathrm{H}), 7.1-7.0(\mathrm{~m}, 2 \mathrm{H}), 6.9(\mathrm{td}, J$ 6.8, $1.2 \mathrm{~Hz}, 1 \mathrm{H}) . \mathrm{NMR}{ }^{13} \mathrm{C}\left(\mathrm{CDCl}_{3}, 75 \mathrm{MHz}\right): \delta=151.3,147.0,135.1,133.2,129.4,128.5,128.4,128.3,126.6$, 126.0, 125.4, 124.4, 117.6, 113.0, 106.2 .MS: $m / z$ (rel. int.) 302 (41.5), 225 (100.0), 193 (15.1), 77 (9.7).

\section{Acknowledgements}

The authors thank the Fundação de Amparo à Pesquisa do Estado do Rio Grande do Sul (FAPERGS) (ARD 16/2551-0000358-0, PqG 17/25510000964-9 and PRONEM 16/2551-0000240-1), Conselho Nacional de Desenvolvimento Científico e Tecnológico (CNPq) and Financiadora de Inovação e Pesquisa (FINEP) for the financial support. CNPq is also acknowledged for the fellowships (DA, GP and EJL). This study was financed in part by the Coordenação de Aperfeiçoamento de Pessoal de Nível Superior - Brasil (CAPES) - Finance Code 001.

\section{Supplementary Material}

Copies of ${ }^{1} \mathrm{H}$ and ${ }^{13} \mathrm{C}$ NMR spectra of compounds 3 and 5.

\section{References}

1. Quin, L. D.; Tyrell, J. A. Fundamentals of Heterocyclic Chemistry; John Wiley \& Sons, Inc. : Hoboken, New Jersey, 2010.

2. Gueiffier, A.; Mavel, S.; Lhassani, M.; Elhakmaoui, A.; Snoeck, R.; Andrei, G.; Chavignon, O.; Teulade, J.-C.; Witvrouw, M.; Balzarini, J.; De Clercq, E.; Chapat, J.-P. J. Med. Chem. 1998, 41, 5108. https://doi.org/10.1021/jm981051y

3. Moraski, G. C.; Markley, L. D.; Hipskind, P. A.; Boshoff, H.; Cho, S.; Franzblau, S. G.; Miller, M. J. ACS Med. Chem. Lett. 2011, 2, 466.

https://doi.org/10.1021/ml200036r

4. Kumar, K.; Sharma, N.; Maurya, I. K.; Bhasin, A. K. K.; Wangoo, N.; Brandão, P.; Félix, V.; Bhasin, K. K.; Sharma, R. K. Eur. J. Med. Chem. 2016, 123, 916.

https://doi.org/10.1016/j.ejmech.2016.07.076

5. Marcinkowska, M.; Kołaczkowski, M.; Kamiński, K.; Bucki, A.; Pawłowski, M.; Siwek, A.; Karcz, T.; Mordyl, B.; Starowicz, G.; Kubowicz, P.; Pękala, E.; Wesołowska, A.; Samochowiec, J.; Mierzejewski, P.; Bienkowski, P. Eur. J. Med. Chem. 2016, 124, 456.

https://doi.org/10.1016/i.ejmech.2016.08.059

6. Dam, J.; Ismail, Z.; Kurebwa, T.; Gangat, N.; Harmse, L.; Marques, H. M.; Lemmerer, A.; Bode, M. L.; De Koning, C. B. Eur. J. Med. Chem. 2017, 126, 353.

https://doi.org/10.1016/j.ejmech.2016.10.041 
7. Goel, R.; Luxami, V.; Paul, K. Curr. Top. Med. Chem. 2016, 16, 3590. https://doi.org/10.2174/1568026616666160414122644

8. Bagdi, A. K.; Santra, S.; Monira, K.; Hajra, A. Chem. Commun. 2015, 51, 1555. https://doi.org/10.1039/C4CC08495K

9. Meng, X.; Yu, C.; Chen, G.; Zhao, P. Catal. Sci. Technol. 2015, 5, 372. https://doi.org/10.1039/C4CY00919C

10. Kalari, S.; Babar, D. A.; Karale, U. B.; Makane, V. B.; Rode, H. B. Tetrahedron Lett. 2017, $58,2818$. https://doi.org/10.1016/j.tetlet.2017.06.010

11. Cao, H.; Zhan, H.; Lin, Y.; Lin, X.; Du, Z.; Jiang, H. Org. Lett. 2012, 14, 1688. https://doi.org/10.1021/ol300232a

12. Xiang, S.; Chen, H.; Liu, Q. Tetrahedron Lett. 2016, 57, 3870. https://doi.org/10.1016/j.tetlet.2016.07.057

13. Cao, H.; Lei, S.; Li, N.; Chen, L.; Liu, J.; Cai, H.; Qiu, S.; Tan, J. Chem. Commun. 2015, 51, 1823. https://doi.org/10.1039/C4CC09134E

14. Ravi, C.; Adimurthy, S. Chem. Rec. 2017, 17, 1019. https://doi.org/10.1002/tcr.201600146

15. Bagdi, A. K.; Mitra, S.; Ghosh, M.; Hajra, A. Org. Biomol. Chem. 2015, 13, 3314. https://doi.org/10.1039/C5OB00033E

16. Ji, X.-M.; Zhou, S.-J.; Chen, F.; Zhang, X.-G.; Tang, R.-Y. Synthesis 2015, 47, 659. https://doi.org/10.1055/s-0034-1379941

17. Rafique, J.; Saba, S.; Rosário, A. R.; Braga, A. L. Chem. Eur. J. 2016, 22, 11854. https://doi.org/10.1002/chem.201600800

18. Vieira, B. M.; Thurow, S.; Brito, J. S.; Perin, G.; Alves, D.; Jacob, R. G.; Santi, C.; Lenardão, E. J. Ultrason. Sonochem. 2015, 27, 192.

https://doi.org/10.1016/j.ultsonch.2015.05.012

19. Rodrigues, I.; Barcellos, A. M.; Belladona, A. L.; Roehrs, J. A.; Cargnelutti, R.; Alves, D.; Perin, G.; Schumacher, R. F. Tetrahedron 2018, 74, 4242. https://doi.org/10.1016/j.tet.2018.06.046

20. Banerjee, B. Ultrason. Sonochem. 2017, 35-A, 15. https://doi.org/10.1016/j.ultsonch.2016.10.010

21. Hiebel, M.-A.; Fall, Y.; Scherrmann, M.-C.; Berteina-Raboin, S. Eur. J. Org. Chem. 2014, 4643. https://doi.org/10.1002/ejoc.201402079

22. Ge, W.; Zhu, X.; Wei, Y. Eur. J. Org. Chem. 2013, 6015. https://doi.org/10.1002/ejoc.201300905

23. Allahabadi, E.; Ebrahimi, S.; Soheilizad, M.; Khoshneviszadeh, M.; Mahdavi, M. Tetrahedron Lett. 2017, 58, 121. https://doi.org/10.1016/i.tetlet.2016.11.081

24. Zhang, H.; Jiang, L. Tetrahedron Lett. 2015, 56, 2777. https://doi.org/10.1016/j.tetlet.2015.04.030

25. Lenardão, E. J.; Santi, C.; Sancineto, L. New frontiers on organoselenium compounds; Springer: Cham, Switzerland, 2018. https://doi.org/10.1007/978-3-319-92405-2 
26. Jain, V. K.; Priyadarsini, K. I. (Eds.) Organoselenium Compounds in Biology and Medicine: Synthesis, Biological and Therapeutic Treatments; Royal Society of Chemistry: Croydon, UK, 2017. https://doi.org/10.1039/9781788011907

27. Santi, C. (Ed.) Organoselenium Chemistry between Synthesis and Biochemistry; Bentham Science Publishers: United Arab Emirates, 2014. https://doi.org/10.2174/97816080583891140101

28. Alberto, E. E.; Braga, A. L. In Selenium and Tellurium Chemistry: From Small Molecules to Biomolecules and Materials; Derek, W. J.; Risto, L. Eds.; Springer: Berlin, 2011 ; pp. 251-283.

https://doi.org/10.1007/978-3-642-20699-3 11

29. Vieira, B. M.; Thurow, S.; da Costa, M.; Casaril, A. M.; Domingues, M.; Schumacher, R. F.; Perin, G.; Alves, D.; Savegnago, L.; Lenardão, E. J. Asian J. Org. Chem. 2017, 6, 1635.

https://doi.org/10.1002/ajoc.201700339

30. Kumar, S.; Sharma, N.; Maurya, I. K.; Verma, A.; Kumar, S.; Bhasin, K. K.; Sharma, R. K. New J. Chem. 2017, 41, 2919. https://doi.org/10.1039/C7NJ00338B

31. Fonseca, S. F.; Padilha, N. B.; Thurow, S.; Roehrs, J. A.; Savegnago, L.; de Souza, M. N.; Fronza, M. G.; Collares, T.; Buss, J.; Seixas, F. K.; Alves, D.; Lenardão, E. J. Ultrason. Sonochem. 2017, 39, 827. https://doi.org/10.1016/j.ultsonch.2017.06.007

32. Casaril, A. M.; Ignasiak, M. T.; Chuang, C. Y.; Vieira, B.; Padilha, N. B.; Carroll, L.; Lenardão, E. J.; Saveg nago, L.; Davies, M. J. Free Rad. Biol. Med. 2017, 113, 395.

https://doi.org/10.1016/j.freeradbiomed.2017.10.344

33. Thompson, L. H.; Doraiswamy, L. K. Ind. Eng. Chem. Res. 1999, 38, 1215. https://doi.org/10.1021/ie9804172

34. Cella, R. In Handbook on Applications of Ultrasound Sonochemistry for Sustainability; Chen, D.; Sharma, S. K.; Mudhoo, A. Eds.; CRC Press: New York, 2012, pp 263-279.

35. Mason, T. J.; Lorimer, J. P. Applied Sonochemistry: Uses of Power Ultrasound in Chemistry and Processing, Wiley-VCH Verlag: Weinheim, 2002.

https://doi.org/10.1002/352760054X

36. Riez, P.; Kondo, T. Free Rad. Biol. Med. 1992, 13, 247. https://doi.org/10.1016/0891-5849(92)90021-8

37. Mendes, S. R.; Thurow, S.; Penteado, F.; da Silva, M. S.; Gariani, R. A.; Perin, G.; Lenardão, E. J. Green Chem. 2015, 17, 4334. https://doi.org/10.1039/C5GC00932D

38. Mojtahedi, M. M.; Abaee, M. S. In Handbook on Applications of Ultrasound Sonochemistry for Sustainability; Chen, D.; Sharma, S. K.; Mudhoo, A. Eds.; CRC Press: New York, 2012, pp. 281-322.

39. Nüchter, M.; Ondruschka, B.; Jungnickel, A.; Müller, U. J. Phys. Org. Chem. 2000, 13, 579. https://doi.org/10.1002/1099-1395(200010)13:10<579::AID-POC272>3.0.CO;2-M

40. Peglow, T. J.; Schumacher, R. F.; Cargnelutti, R.; Reis, A. S.; Luchese, C.; Wilhelm, E. A.; Perin, G. Tetrahedron Lett. 2017, 58, 3734. https://doi.org/10.1016/i.tetlet.2017.08.030

41. Birmann, P. T.; Sousa, F. S. S.; de Oliveira, D. H.; Domingues, M.; Vieira, B. M.; Lenardão, E. J.; Savegnago, L. Eur. J. Pharmacol. 2018, 827, 71. https://doi.org/10.1016/j.ejphar.2018.03.005 
42. Perin, G.; Alves, D.; Jacob, R. G.; Barcellos, A. M.; Soares, L. K.; Lenardão, E. J. ChemistrySelect 2016, 1, 205. https://doi.org/10.1002/slct.201500031

43. Brotherton, W. S.; Clark, R. J.; Zhu, L. J. Org. Chem. 2012, 77, 6443.

https://doi.org/10.1021/jo300841c

44. Pires, C. S.; de Oliveira, D. H.; Pontel, M. R. B.; Kazmierczak, J. C.; Cargnelutti, R.; Alves, D.; Jacob, R. G.; Schumacher, R. F. Beilstein J. Org. Chem. 2018, 14, 2789.

https://doi.org/10.3762/bjoc.14.256

45. Jadhav, S. A.; Shioorkara, M. G.; Chavanb, O. S.; Sarkatec, A. P.; Shinded, D. B. Synth. Commun. 2017, 47, 285.

https://doi.org/10.1080/00397911.2016.1262040

46. Lou, Z.; Yang, H.; Zhu, C.; Fu, H. Asian J. Org. Chem. 2017, 6, 1551. https://doi.org/10.1002/ajoc.201700381

47. Mutai, T.; Tomoda, H.; Ohkawa, T.; Yabe, Y.; Araki, K. Angew. Chem. Int. Ed. 2008, 47, 9522. https://doi.org/10.1002/anie.200803975 